\title{
САМОСТАВЛЕННЯ АВАНТЮРНИХ ОСІБ: ПОШУК ВІДМІННОСТЕЙ
}

\author{
Наталя Меленчук \\ кандидат психологічних наук, викладач кафедри \\ загальної та диференціальної психології \\ Південноукраїнський національний педагогічний \\ університет імені К. Д. Ушинського, \\ 65020, Україна, м. Одеса, вул. Старопортофранківська, 26 \\ Natmelenchuk0808@,gmail.com, http://orcid.org/0000-0002-4749-6889
}

\section{Анотація}

В цій статті презентовано результати дослідження самоставлення осіб з різним рівнем авантюрності. Здійснено аналіз досліджень щодо визначення таких феноменів, як: «авантюрність», «самоставлення». Авантюрність, як складна властивість особистості, розглядається з позицій континуально-ієрархічного підходу до структури особистості. Актуальність розробки проблеми пов'язана 3 потребою вивчення властивостей особистості, котрі вимагають від особистості сміливих, швидких, а інколи й ризикованих дій в умовах високої невизначеності. Такою властивістю $є$ схильність особистості до авантюрної поведінки (авантюрності). Ми припустили, що авантюрна особистість, за даними літератури, має позитивне ставлення до себе. Для емпіричної перевірки було обрано: оригінальний психодіагностичний «Тест-опитувальник схильності до авантюрності» (АВАНТ-1)» О. П. Саннікової, О. І. Саннікова, Н. І. Меленчук і методику «Тест-опитувальник самоставлення особистості» Встановлено статистично значимі взаємозв'язки показників авантюрності i самоставлення. Якісний аналіз за допомогою методу асів і профілів дозволив вивчити психологічні особливості самоставлення осіб, які різняться рівнем авантюрності. Показано, що особи з низьким рівнем авантюрності в даній виборці $є$ схильними до більшого самоприйняття, схвалення себе в цілому і більш позитивного ставлення до себе. Особи з високим рівнем авантюрності, характеризуються невисокими значеннями за показниками самоставлення та відсутністю негативних емоцій в сторону свого «Я». Представники групи осіб з високим рівнем авантюрності не готові поставити собі в провину свої промахи, невдачі, власні недоліки і не схильні до самозвинувачення. Таким чином, в роботі доведено припущення про те, що авантюрні особи, хоча за рівнем нижче, ніж не авантюрні особи, характеризуються позитивним самоставленням, самоінтересом, саморозумінням, самоповагою, аутосимпатією, самовпевненістю.

Ключові слова: авантюрність, схильність до авантюрної поведінки, самоставлення, властивість особистості, кількісний аналіз, якісний аналіз.

\section{Вступ}

Стрімкі перетворення, що відбуваються в сучасному суспільстві, збільшують ваги невизначених i ризикованих ситуацій в життєдіяльності людини. Властивістю 
особистості, котра допомагає успішно функціонувати в непередбачуваному просторі сучасного світу, є схильність особистості до авантюрної поведінки (авантюрності).

В психології вивчення проблеми схильності до авантюрної поведінки пов'язане 3 дослідженням індивідуально-психологічних особливостей авантюрності, що виявляються в різних ситуаціях ризику і невизначеності й можуть сприяти або запобігати успішній життєдіяльності особистості. Серед рис особистості, що мають важливе значення як для процесу соціальної адаптації, так i для регуляції поведінки, виокремлюються: самоставлення, адаптивність, впевненість, сміливість, заповзятливість, товариськість, емоційна стійкість, толерантність до невизначеності тощо (Тимофеева, 2005; Melenchuk, 2017). Це дало підстави припустити, що авантюрним особам властиво позитивне самоставлення, самоінтерес, саморозуміння, самоповага.

Незважаючи на те, що питання самоставлення особистості $\epsilon$ для психології традиційним об'єктом дослідження, але й сьогодні воно $є$ досить актуальним. Це пояснюється тим, що адекватне ставлення людини до самої себе $є$ запорукою благополучного функціонування особистості як суб'єкта життєдіяльності. Самоставлення впливає на прояв соціальної активності людини, на процеси самоактуалізації, самовдосконалення, самореалізації. Кожна людина стикається з визначенням свого місця в житті, що залежить від того, наскільки особистість цінує і поважає себе, приймає і розуміє свої вчинки, критично оцінює власні успіхи тощо.

До найбільш розповсюджених категорій, що розкривають сутність ставлення людини до себе, можна виокремити такі: «глобальна (загальна) самооцінка», «самоповага», «самоставлення» і «емоційно-ціннісне ставлення до себе» (Колышко, 2004).

На даний час в психологічної літературі самоставлення розглядається як емоційний компонент самосвідомості, який, з одного боку, спирається на самопізнання, а з іншого створює головні передумови для формування саморегуляції і саморозвитку (Бодалев \& Столин, 2002; Кириллов, 1992; Колышко, 2004; Пантилеев, 1991). Так, у розробленій В. В. Століним концепції самосвідомості, самоставлення і самопізнання пов'язані опосередковано, за допомогою самооцінки. На рівні свідомості самоставлення виявляється у поведінці та діяльності як глобальне почуття «за» або «проти» самого себе у формі самоповаги, аутосимпатії, самоінтересу, очікуваного ставлення з боку навколишніх (Бодалев \& Столин, 2002). С. Р. Пантілєєв розуміє самоставлення як емоційно-оцінну систему індивіда до самого себе (Пантилеев, 1991).

Авантюрність в цій роботі розуміється як складна багаторівнева властивість особистості, психологічна сутність якої виявляється у надії на легкий і швидкий успіх, вдачу при наявності кінцевої мети, яка є принадливою для особистості, без ретельного аналізу реальних зовнішніх обставин, власних можливостей (ресурсів), шляхів вирішення проблеми задля досягнення мети (Меленчук, 2016, 2017; Саннікова, Санніков \& Меленчук, 2015).

Спираючись на позиції континуально-ієрархічної концепції структури особистості, запропонованої О. П. Санніковою (Санникова, 2003), макроструктура авантюрності, як складної багаторівневої властивості особистості, може бути представлена за трьома рівнями: формально-динамічним, змістовним і соціально-імперативним, кожен 3 яких характеризується своїм специфічним змістом. Ознаки авантюрності на формальнодинамічному рівні виявляються в особливостях іiї виникнення та перебігу, відображують 
форму реалізації в різних ситуаціях. На якісному рівні авантюрність містить характеристики, що відображають іiі психологічну сутність. На змістово-особистісному рівні авантюрність виявляється в характеристиках, що пов'язані із спрямованістю особистості, її потребо-мотиваційною сферою, цінностями, світоглядом, інтересами тощо (Меленчук, 2016; Саннікова, Санніков \& Меленчук, 2015).

В основі авантюрної поведінки лежать не тільки специфічні особливості небезпечних, невизначених ситуацій, але й індивідуально-психологічні особливості суб'єкта діяльності, його психологічні стани та властивості особистості. Аналіз доступних наукових досліджень продемонстрував відсутність робіт, в яких вивчається авантюрність у зв'язку із самоставленням особистості. Але, є незначна кількість робіт, де авантюрність і самоставлення поєднуються в певному контексті.

Так, самоставлення як стійка риса особистості, тісно пов'язана 3 іншими властивостями особистості, особливо волею. Воно здійснює вплив на формування змісту, структури і форми прояву цілої системи психологічних особливостей особистості. Ставлення особистості до себе виступає мотивом саморегуляції поведінки й Ничкало, 2001) актуалізується на всіх етапах здійснення поведінкового акту (Колышко, 2004).

Існує багато психологічних досліджень, в яких встановлено тісний зв'язок між ставленням особистості до себе як до суб'єкта життєвих взаємин та її поведінкою. В них зазначається, що висока самоповага особистості виступає умовою іiі максимальної активності, продуктивності в діяльності, реалізації творчого потенціалу, впливає на свободу прояву почуттів, рівень саморозкриття в спілкуванні (Кириллов, 1992; Колышко, 2004). Існуючі теоретичні і емпіричні дослідження свідчать про те, що позитивне стійке самоставлення пов'язано з вірою людини в свої можливості, самостійністю, енергійністю, готовністю до ризикованих і авантюрних дій, впевненістю в успішності своїх дій в ситуації невизначеності (Кириллов, 1992; Колышко, 2004; Меленчук, 2016).

В свою чергу, негативне самоставлення, на відміну від позитивного, є тим чинником, через який поведінка людини приймає ригідну, агресивну, неадаптивну i асоціальну форми. Така людина впевнена в поганому ставленні до неї оточуючих (Бодалев \& Столин, 2002; Пантилеев, 1991). Негативне самоставлення виявляється в збільшенні самозвинувачення, зниженні переконаності в цінності своєї особистості, внаслідок чого зростає емоційність і знижується рівень активності (Кочеткова, 2007).

На думку К. Леонгарда, одним із мотивів авантюрної поведінки $є$ «потреба у визнанні». Авантюрні особистості характеризуються потужним завзяттям, з яким вони домагаються свого визнання, самовпевненістю i зарозумілістю. До словесного самовихваляння приєднується гонорова поведінка, прагнення всіляко привернути до себе увагу присутніх. Також автор звертає увагу на таку характерну для авантюристичної особистості рису, як відсутність схильності до обмірковування своїх вчинків. Незважаючи на те, що для авантюриста дуже важливе враження, яке він справляє на оточуючих, авантюрна особистість не здатна заздалегідь обміркувати лінію своєї поведінки, завжди живе моментом (Леонгард, 1989).

Л. А. Кіріллов в своєму дослідженні, присвяченому вивченню індивідуальнотипологічних особливостей самосвідомості акцентуйованих особистостей, встановив, що гіпертимні та істероїдні типи усвідомлюють себе як «самоефективні» у вирішенні всіх 
актуальних проблем і подоланні труднощів. Їх «Я-в-майбутньому» - це «Я-успішний» (Кириллов, 1992).

Враховуючи вкрай низький ступінь розробленості проблеми взаємозв'язку самоставлення і авантюрності, в цій статті ми робимо спробу аналізу означеної проблеми на підставі всіх наявних даних, що прямо або опосередковано відносяться до різних іiі аспектів.

Метою дослідження $\epsilon$ аналіз результатів теоретичного обгрунтування та емпіричного вивчення особливостей самоставлення осіб, які схильні та несхильні до авантюрної поведінки. Завдання дослідження: 1) на основі теоретико-методологічного аналізу наукових джерел уточнити сутність феноменів «схильність до авантюрної поведінки» («авантюрність) і «самоставлення»; 2) підібрати комплекс психодіагностичних методик, спрямований на діагностику авантюрності й самоставлення; 3) емпірично визначити характер співвідношень показників авантюрності та самоставлення; 4) дослідити специфіку самоставлення осіб, схильних до авантюрної поведінки різного ступеня.

\section{Методи дослідження}

В емпіричному дослідженні приймали участь 79 осіб у віці від 24 до 45 років (магістри заочної та денної форми навчання соціально-гуманітарного факультету Державного закладу «Південноукраїнський національний університет імені К. Д. Ушинського»).

Для діагностики самоставлення застосовано методику «Тест-опитувальник самоставлення особистості» С. Р. Пантілєєва, В. В. Століна. Зазначена методика дозволяє виявити три рівні самоставлення, що відрізняються мірою узагальненості: 1) глобальне самоставлення; 2) самоставлення, що $\epsilon$ диференційованим за самоповагою, аутосимпатією, самоінтересом та очікуваним ставленням до себе; 3) рівень конкретних дій у відношенні до свого «Я» (Колишко, 2004; Пантилеев, 1991). Вивчення авантюрності здійснено за допомогою «Тест-опитувальника схильності до авантюрності» (АВАНТ-1) О. П. Саннікової, О. І. Саннікова, Н. І. Меленчук (Саннікова, Санніков \& Меленчук, 2015).

Статистична обробка даних проводилась 3 використанням комп’ютерної програми SPSS 21.0 for Windows. Використовувались кількісний (кореляційний, t-критерій Ст’юдента) та якісний (метод «асів» і метод «профілів») аналізи даних.

\section{Результати та дискусії}

Попередньо проведений кореляційний аналіз допоміг встановити характер взаємозв'язків між показниками авантюрності і показниками самоставлення (див. табл. 1).

Аналіз табл. 1 виявив значимі, переважно від'ємні, кореляційні взаємозв’язки між більшістю показників самоставлення, крім показників ставлення до інших (С2), самоінтерес (C6) і саморозуміння (C7), та всіма показниками авантюрності. Так, установчий показник авантюрності (AvUst) встановив значимі від'ємні кореляційні взаємозв'язки майже з усіма показниками самоставлення: інтегральним показником (S), самоповагою (CI), аутосимпатією (CII), очікуванням позитивного ставлення від інших (CIII), самовпевненістю (C1) на $1 \%$ рівні; 3 показниками самоприйняття (C3), 
самокерівництво (C4) - на 5\% рівні; а 3 показником самозвинувачення (C5) виявив додатний значимий зв'язок на 5\% рівні.

Таблиия 1

\section{Значимі коефіціснти кореляцій між показниками авантюрності та показниками самоставлення}

\begin{tabular}{|c|c|c|c|c|c|c|c|}
\hline \multirow{2}{*}{$\begin{array}{c}\text { Показники } \\
\text { самоставлення }\end{array}$} & \multicolumn{7}{|c|}{ Показники авантюрності } \\
\hline & AvUst & AvEM & AvKk & AvKo & $\mathrm{AvPo}$ & $\mathrm{AvKr}$ & $\mathrm{AvOb}$ \\
\hline $\mathrm{S}$ & $-356^{* *}$ & & $-236^{*}$ & & $-280^{*}$ & $277^{*}$ & \\
\hline $\mathrm{CI}$ & $-369^{* *}$ & & & & & & \\
\hline CII & $-366^{* *}$ & & & $-278^{*}$ & $-271^{*}$ & $386^{* *}$ & $-270^{*}$ \\
\hline CIII & $-307^{* *}$ & & & & & & \\
\hline CIV & & & $-345^{* *}$ & $-237^{*}$ & & & $-229^{*}$ \\
\hline $\mathrm{C} 1$ & $-410^{* *}$ & & $-305^{* *}$ & $-284^{*}$ & $-225^{*}$ & $380^{* *}$ & $-255^{*}$ \\
\hline C3 & $-279^{*}$ & & & $-298^{* * *}$ & $-222^{*}$ & & \\
\hline $\mathrm{C} 4$ & $-281^{*}$ & $-269^{*}$ & & & & & \\
\hline $\mathrm{C} 5$ & $258^{*}$ & & & & & $-271^{*}$ & \\
\hline
\end{tabular}

Примітка: 1) нулі та коми опущені; 2) позначення ** - значущість зв'язку на рівні $\mathrm{p} \leq 0.01 ; *-\mathrm{p} \leq 0.05 ; 3)$ умовні позначення показників авантюрності: AvUst - установчий показник; AvEM - емоційно-мотиваційний показник; AvKk - когнітивний показник; AvKo - конативний показник; AvPo - чутливість до авантюрних дій; $\mathrm{AvKr}$ - контрольнорегулятивний показник; $\mathrm{AvOb}$ - загальний показник схильності до авантюрності; 4) умовні позначення показників самоставлення: S - інтегральний показник, CI самоповага, CII - аутосимпатія, CIII - очікування позитивного ставлення від інших, CIV самоінтерес, C1 - самовпевненість, С3 - самоприйняття, С4 - самокерівництво, С5 самозвинувачення.

Емоційно-мотиваційний показник авантюрності (AvEM) продемонстрував лише один від'ємний значимий зв'язок на 5\% рівні з таким показником самоставлення, як самокерівництво (C4). Когнітивний показник авантюрності (AvKk) має значимі від'ємні кореляційні зв'язки з інтегральним показником самоставлення (S) на 5\% рівні, а 3 показниками самоінтерес (CIV) і самовпевненість (C1) - на 1\% рівні. Конативний показник авантюрності (AvKo) від'ємно на $1 \%$ рівні пов'язаний 3 показником самоставлення самоприйняття (C3), і на 5\% рівні 3 показниками аутосимпатія (CII), самоінтерес (CIV), самовпевненість (C1). Такий показник авантюрності, як чутливість до авантюрних дій (AvPo) встановив значимі від'ємні зв'язки на 5\% рівні з інтегральним показником самоставлення (S), аутосимпатією (CII), самовпевненістю (C1) i самоприйняттям (C3).

Варто звернути особливу увагу на результати кореляційного аналізу між контрольно-регулятивним показником авантюрності (AvKr) i показниками самоприйняття. На відміну від інших показників авантюрності, він виявив протилежні значимі зв'язки з показниками аутосимпатія (CII), самоінтерес (CIV) і самовпевненість (C1). I лише з показником самозвинувачення (C5) встановив значимий від'ємний зв'язок на 5\% рівні. I, нарешті, загальний показник схильності до авантюрності (AvOb) від’ємно 
на 5\% рівні пов'язаний з такими показниками самоставлення, як: аутосимпатія (CII), самоінтерес (CIV) і самовпевненість (C1).

Такі результати кореляційного аналізу можна пояснити тим, що в масовій свідомості авантюрність розуміється як негативна властивість. Таке уявлення про авантюрну поведінку притаманно більш дорослому поколінню, яке не дозволяє собі ніяких проявів авантюрної поведінки. А як вже було зазначено, до нашої вибірки увійшли особи у віці від 24 до 45 років. Це припущення підтвердилось і завдяки усному опитуванню, в якому обстежені охарактеризували авантюрність як негативну поведінку. На наш погляд, такий суперечливий результат потребує спростування або підтвердження за допомогою додаткового дослідження на іншій виборці.

Варто зазначити, що наявність кореляційних взаємозв'язків констатує лише взаємозв'язок між показниками, але не означає наявність причинно-наслідкового зв'язку між ними. Використання якісного аналізу дозволило вивчити особливості самоставлення в осіб з високим і низьким рівнем авантюрності. Попередньо, за допомогою методу «асів» (Саннікова, 2003) було виділено зазначені групи осіб: група Av+ i група Av-. Далі, із застосуванням методу «профілів», було досліджено специфіку самоставлення осіб, які відрізняються за рівнем авантюрності.

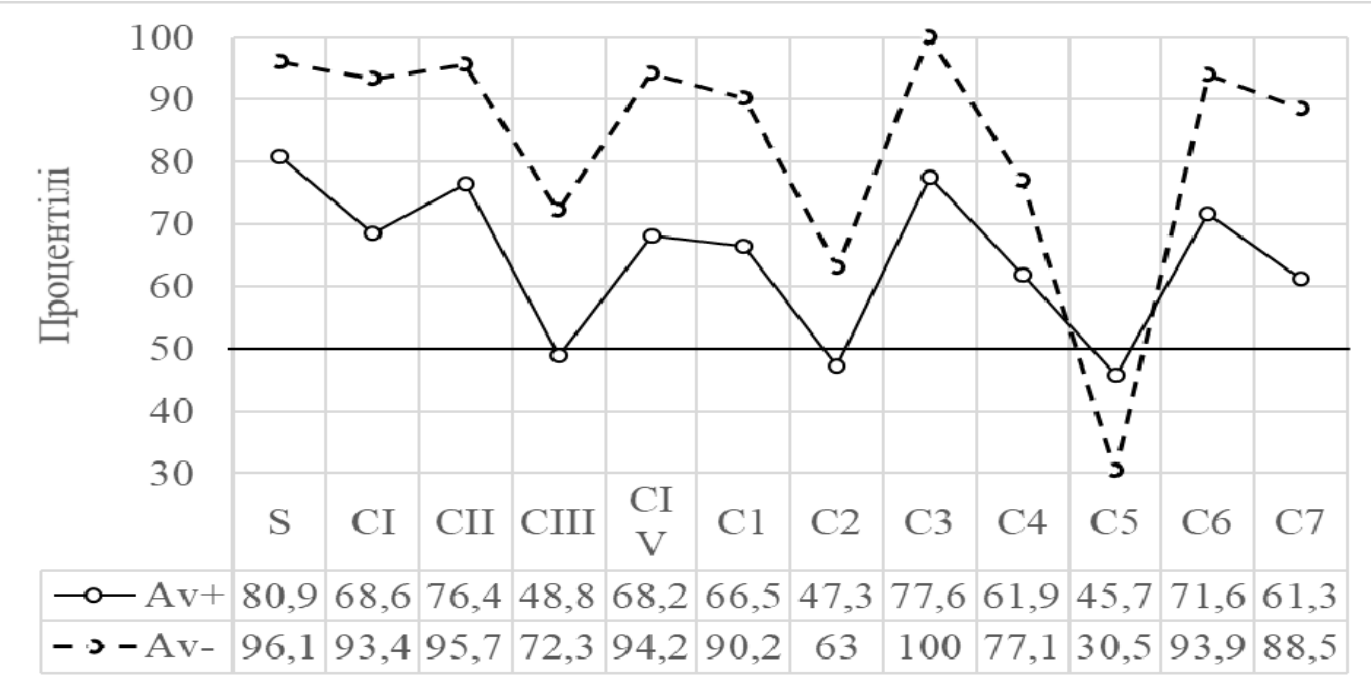

Рис. 1. Профілі самоставлення груп осіб, які схильні і несхильні до авантюрності

Примітка: 1) група Av+ (n=14) - група осіб з високим рівнем загального показника схильності до авантюрності; група Av- $(\mathrm{n}=14)$ - група осіб з низьким рівнем загального показника схильності до авантюрності; 2) умовні позначення показників самоставлення: $\mathrm{S}$ - інтегральний показник, CI - самоповага, CII - аутосимпатія, CIII - очікування позитивного ставлення від інших, CIV - самоінтерес, C1 - самовпевненість, С2 ставлення до інших, С3 - самоприйняття, С4 - самокерівництво, С5 - самозвинувачення, С6 - самоінтерес, С7 - саморозуміння.

Отже, на рис. 1 презентовано профілі самоставлення виділених груп осіб. На осі OX розміщені показники самоставлення, на осі ОУ - їх значення, що надано у процентілях. Середня лінія ряду проходить через точку 50-й процентіль. Кожний профіль відображає середні значення відповідних показників усіх представників виділених груп. Візуально профілі самоставлення розташовані переважно у додатному просторі значень 
(над середньою лінією ряду), що свідчить про позитивні тенденції у проявах самоставлення двох груп осіб.

3 метою аналізу кожного профілю здійснено ранжування показників самоставлення за відхиленням від середньої лінії ряду (від збільшення абсолютного числа до меншого). Валентність означає відхилення від середньої лінії ряду або до додатного, або до від'ємного полюсу. Результати ранжування надано у табл. 2.

Таблиия 2

Ранжування показників самоставлення осіб із високим і низьким рівнем авантюрності

\begin{tabular}{|c|c|c|}
\hline \multirow{2}{*}{ Ранг } & \multicolumn{2}{|c|}{ Групи осіб з різним рівнем авантюрності } \\
\cline { 2 - 3 } & $\mathrm{S}^{+}$інтегральний показник & Група Av- \\
\hline 1 & $\mathrm{C3}^{+}$самоприйняття & $\mathrm{C}^{+}$самоприйняття \\
\hline 2 & $\mathrm{CII}^{+}$аутосимпатія & $\mathrm{S}^{+}$інтегральний показник \\
\hline 2 & $\mathrm{C6}^{+}$самоінтерес & $\mathrm{CII}^{+}$аутосимпатія \\
\hline 3 & $\mathrm{C5}^{-}$відсутність самозвинувачення & $\mathrm{CIV}^{+}$самоінтерес \\
\hline 4 & Примітка: показники надано у порядку & зменшення абсолютних величин \\
\hline
\end{tabular}
відхилення від середньої лінії ряду.

Враховуючи змістовий опис показників самоставлення, що пропонується авторами застосованої методики, спробуємо проаналізувати означені профілі (рис. 1).

Перш за все, аналіз профілів свідчить про те, що за загальним фактором S (загальне самоставлення «за» або «проти» власного Я) обидві групи обстежених продемонстрували високий і майже однаковий результат.

За показником аутосимпатія $\left(\mathrm{CII}^{+}\right)$також не встановлено розбіжностей між двома групами. Значення цього показника досить високе для представників «авантюрних» i «неавантюрних» груп осіб, що свідчить про дружність до власного «Я», «самоприйняття». Обстежені виявляють схвалення себе як в цілому, так і в істотних деталях, довіру до себе i позитивну самооцінку, відчувають до самих себе позитивні емоції.

За показником самоприйняття $\left(\mathrm{C} 3^{+}\right)$також встановлено близькі результати в обох групах осіб. Отже, цим особам притаманно почуття симпатії до себе, прийняття себе таким, який є, навіть з деякими недоліками, згода зі своїми внутрішніми спонуканнями, поблажливе, дружнє ставленням до себе. Можна відмітити, що в осіб, не які схильні до авантюрності (група Av-), цей показник вище, ніж в осіб, які схильні до авантюрності (група $\mathrm{Av}+$ ).

Але за фактором самозвинувачення (С5) встановлено розбіжності між двома групами осіб. В групі «авантюрних осіб» (група $\mathrm{Av}+$ ) цей показник є більш вираженим. Це вказує на відсутність негативних емоцій в сторону свого «Я». Особи, які схильні до авантюрності, не готові поставити собі в провину свої промахи і невдачі, власні недоліки. Вони не схильні до самозвинувачення.

За показником самоінтерес $\left(\mathrm{CIV}^{+}\right)$також встановлено незначні розбіжності між двома групами. Його значення більш високі у представників групи «неавантюрних осіб» (група Av-). Так, показник самоінтересу $\left(\mathrm{CIV}^{+}\right)$відображає, наскільки людина є близькою 
до самої себе, до свої почуттів, наскільки вона впевнена в тому, що є цікавою для оточуючих. Високі значення за цим показником свідчать про те, що ці особи знаходяться в гармонії із самими собою, виявляють інтерес до власних думок і почуттів, готові спілкуватися з собою «на рівних», впевнені в тому, що вони викликають інтерес в оточуючих людей.

Показник самоповаги $\left(\mathrm{CI}^{+}\right)$відображає віру людини у свої сили, здібності, енергію, іiі самостійність, адекватну оцінку своєї здатності контролювати життя. Представникам групи осіб із низьким рівнем авантюрності (група Av-) характерні більш високі значення за цим показником. В них більш виражені саморозуміння, віра в свої сили, самостійність, позитивна оцінка своїх можливостей, готовність контролювати власне життя і бути самопослідовним, розуміння самого себе.

Отже, можна констатувати, що представники обох груп осіб мають досить високі значення показників самоприйняття, схвалюють себе в цілому, довіряють собі та позитивно себе оцінюють.

Відмінності між проявами самоставлення в групах, що вивчаються, були підтверджені за допомогою непараметричного t-критерія Ст’юдента (табл. 3).

Таблиия 3

\section{Значення t-критерію Ст'юдента між однойменними показниками самоставлення у підвибірках, що порівнюються}

\begin{tabular}{|c|c|c|c|c|}
\hline \multirow{2}{*}{$\begin{array}{c}\text { Група Av+ / } \\
\text { група Av- }\end{array}$} & \multicolumn{4}{|c|}{ Показники самоставлення, що порівнюються } \\
\hline & $\mathrm{S}$ & CI & CII & CIII \\
\hline t-критерій & $-4,071 * *$ & $-3,048 * *$ & $-5,936 * * *$ & $-4,048 * *$ \\
\hline \multirow{2}{*}{$\begin{array}{c}\text { Група Av+ / } \\
\text { група Av- }\end{array}$} & \multicolumn{4}{|c|}{ Показники самоставлення, що порівнюються } \\
\hline & CIV & $\mathrm{C} 1$ & $\mathrm{C} 2$ & C3 \\
\hline t-критерій & $-2,939 *$ & $-3,239 * *$ & $-2,486^{*}$ & $-3,680 * *$ \\
\hline \multirow{2}{*}{$\begin{array}{c}\text { Група Av+/ } \\
\text { група Av- }\end{array}$} & \multicolumn{4}{|c|}{ Показники самоставлення, що порівнюються } \\
\hline & $\mathrm{C} 4$ & $\mathrm{C} 5$ & $\mathrm{C} 6$ & $\mathrm{C} 7$ \\
\hline t-критерій & $-1,913$ & 1,901 & $-2,414 *$ & $-2,987 * *$ \\
\hline
\end{tabular}

Примітка: 1) рівні значущості: позначка «*» - на значиму відмінність $(\mathrm{p} \leq 0,5)$; позначка «**» та «***» - на високу значиму відмінність $(\mathrm{p} \leq 0,01)$ та $(\mathrm{p} \leq 0,001) ; 2)$ додатний знак перед значенням t-критерія Ст'юдента означає, що даний однойменний показник за значенням вище в першій групі; від’ємний знак - на більше значення показника в другій групі.

Таким чином, аналіз табл. 3 демонструє наявність значимих розбіжностей майже між усіма однойменними показниками самоставлення (окрім показників самокерівництво (C4), самозвинувачення (C5)). Це свідчить про те, що авантюрні особи, хоча за рівнем нижче, ніж не авантюрні особи, характеризуються позитивним ставленням до себе, самоінтересом, саморозумінням, самоповагою, аутосимпатією, самовпевненістю.

\section{Висновки}

1. Теоретично встановлено, що авантюрність - це складна багаторівнева властивість особистості, психологічна сутність якої виявляється у надії на легкий i 
швидкий успіх, вдачу при наявності кінцевої мети, яка є принадливою для особистості, без ретельного аналізу реальних зовнішніх обставин, власних можливостей (ресурсів), шляхів вирішення проблеми задля досягнення мети. Самоставлення розглядається як емоційний компонент самосвідомості, який, з одного боку, спирається на самопізнання, а з іншого - створює головні передумови для формування саморегуляції і саморозвитку.

2. Вивчення специфіки самоставлення здійснювалося в осіб із різним рівнем авантюрності. Для емпіричного дослідження застосовано оригінальний психодіагностичний «Тест-опитувальник схильності до авантюрності» (АВАНТ-1) О. П. Саннікової, О. І. Саннікова, Н. І. Меленчук і методику «Тест-опитувальник самоставлення особистості» С. Р. Пантілєєва, В. В. Століна.

3. Встановлено переважно від'ємні, кореляційні взаємозв'язки між усіма показниками авантюрності і більшістю показників самоставлення, крім показників ставлення до інших (C2), самоінтерес (C6) і саморозуміння (C7).

4. Якісний аналіз за допомогою методу «асів» і «профілів» показав, що особи 3 низьким рівнем авантюрності в даній виборці є схильними до більшого самоприйняття, схвалення себе в цілому і більш позитивного ставлення до себе. Особи з високим рівнем авантюрності, характеризуються невисокими значеннями за показниками самоставлення та відсутністю негативних емоцій в сторону свого «Я». Представники групи осіб 3 високим рівнем авантюрності не готові поставити собі в провину свої промахи, невдачі, власні недоліки і не схильні до самозвинувачення

Перспективи подальших досліджень полягатимуть у вивченні взаємозв'язків авантюрності із широким спектром рис особистості, вдосконалення методів психодіагностики показників авантюрності як багаторівневої властивості особистості. Особливої уваги заслуговує вивчення чинників авантюрної поведінки, розробка засобів корекції неадаптивної авантюрності та рис особистості, що супроводжують її прояви.

\section{Література:}

1. Бодалев, А.А., \& Столин, В.В. (2002). Общзая психодиагностика. СПб.: Речь.

2. Кириллов, Л.А. (1992). Особенности самосознания лиц с акцентуациями характера (Автореф. дис. канд. психол. наук). Москва.

3. Колышко, А.М. (2004). Психология самоотношения. Гродно: ГрГУ.

4. Кочеткова, Т.В. (2007). Специфика видов самоотношения личности в зависимости от выраженности эмоциональных и когнитивных компонентов (Автореф. дис. канд. психол. наук). Хабаровск.

5. Леонгард, К. (1989). Акцентуированные личности. Москва : Феникс.

6. Меленчук, Н.I. (2016). Психологічні чинники схильності особистості до авантюрної поведінки. (Дис. канд. психол. наук). Одеса.

7. Пантилеев, С.Р. (1991). Самоотношение как эмочиионально-оченочная система. Москва : Изд-во МГУ.

8. Санникова, О.П. (2003). Феноменология личности: Избранные психологические труды. Одесса : СМИЛ.

9. Саннікова, О.П., Санніков, О.І., \& Меленчук, Н.I. (2015). А.с. Психодіагностика авантюрності: «Тест-опитувальник схильності до авантюрності» (АВАНТ-1); «Самооиінка компонентів авантюрності», Заявка № 60141; реєстрац. № 59701. 
10. Тимофеева, И.Ю. (2005). Авантюризм в русской культуре конца XVII - первой четверти XIX века. (Дис. канд. культурологических наук). Комсомольск-на-Амуре.

11. Melenchuk, N. (2017). Individual Psychological Peculiarities of Adventurousness According to Emotional Tуре. Наука і освіта, 7, 130-135. https://doi.org/10.24195/2414$\underline{4665-2017-7-20}$

\section{References}

1. Bodalev, A.A., \& Stolin, V.V. (2002). Obshchaia psikhodiagnostika [General psychodiagnosis]. SPb.: Rech [in Russian].

2. Kirillov, L.A. (1992). Osobennosti samosoznaniia lits s aktsentuatsiiami kharaktera [Features of self-identity of persons with accentuations of character]. Extended abstract of Candidate's thesis. Moskva [in Russian].

3. Kolyshko, A.M. (2004). Psikhologiia samootnosheniia [Psychology of self- attitude]. Grodno: GrGU [in Russian].

4. Kochetkova, T.V. (2007). Spetsifika vidov samootnosheniia lichnosti v zavisimosti ot vyrazhennosti emotsionalnykh i kognitivnykh komponentov [The specifics of the types of self-relationship of a person, depending on the severity of emotional and cognitive components]. Extended abstract of Candidate's thesis. Khabarovsk [in Ukrainian].

5. Leongard, K. (1989). Aktsentuirovannye lichnosti [Accented personalities]. Moskva : Feniks [in Russian].

6. Melenchuk, N.I. (2016). Psykholohichni chynnyky skhylnosti osobystosti do avantiurnoi povedinky [Psychological factors of propensity of the individual to adventurous behavior]. Candidate's thesis. Odesa [in Ukrainian].

7. Pantileev, S.R. (1991). Samootnoshenie kak emotsionalno-otsenochnaia sistema [Selfattitude as an emotional-evaluative system]. Moskva : Izd-vo MGU [in Russian].

8. Sannikova, O.P. (2003). Fenomenologiia lichnosti: Izbrannye psikhologicheskie trudy [Personality Phenomenology: Selected Psychological Works]. Odessa : SMIL [in Ukrainian].

9. Sannikova, O.P., Sannikov, O.I., \& Melenchuk, N.I. (2015). A.s. Psykhodiahnostyka avantiurnosti: "Test-opytuvalnyk skhylnosti do avantiurnosti» (AVANT-1); "Samootsinka komponentiv avantiurnosti» [A.s. Adventurous Psychodiagnostics: «Test-questionnaire to define the tendency to adventurism» (AVANT-1); «Self-Assessment of Adventure Components»]. Zaiavka № 60141; reiestrats. № 59701 [in Ukrainian].

10. Timofeeva, I.Iu. (2005). Avantiurizm v russkoi kulture kontsa XVII - pervoi chetverti XIX veka [Adventurism in Russian culture of the end of the XVII - the first quarter of the XIX century]. Candidate's thesis. Komsomolsk-na-Amure [in Russian].

11. Melenchuk, N. (2017). Individual Psychological Peculiarities of Adventurousness According to Emotional Tуре. Наука і освіта, 7, 130-135. https://doi.org/10.24195/24144665-2017-7-20 [in Ukrainian]. 


\title{
ADVENTUROUS PEOPLE'S SELF-ESTEEM: FINDING DIFFERENCES Natalia Melenchuk \\ PhD in Psychology, Lecturer of the Department of General and Differential Psychology \\ South Ukrainian National Pedagogical Ushynskyi University, 26, Staroportofrankivska Str., Odesa, Ukraine, 65020 \\ Natmelenchuk0808@gmail.com, http://orcid.org/0000-0002-4749-6889
}

\begin{abstract}
This article presents the results of the study of the of individuals' self-esteem with different levels of adventurousness. The researches on the definition of such phenomena as «adventurism» and «self-attitude» were analyzed. The adventurism as a complex personality property is viewed from the stance of a continuum-hierarchical approach to personality structure. The urgency of developing the problem is connected with the need to study the properties of personality that require the identity of a brave, fast, and sometimes risky actions in conditions of high uncertainty. Such personality trait is the tendency of a person to adventurous behavior. We assumed that an adventurous person, according to the literature, has a positive attitude to oneself. For empirical testing we chose the original psychodiagnostic «Test-questionnaire to define the tendency to adventurism» (AVANT-1)» by O. Sannikova, O. Sannikov, N. Melenchuk and the method of «Test-questionnaire person self-attitude» by S. Pantileiev and V. Stolin. The statistically significant correlations of the indicators of adventurism and self-attitude has been determined. Qualitative analysis including the method of asses and profiles has allowed to study the psychological peculiarities of the self-attitude of persons with a different level of adventurism. It is shown that individuals with a low level of adventurism in this sample have a tendency to greater self-acceptance, the approval of themselves in general and a more positive attitude towards themselves. Persons with a high level of adventurism are characterized by low values of self-attitude and the absence of negative emotions towards their self-image. The representatives of a group of people with a high level of adventurism are not ready to put themselves in the guilt of their mistakes, failures, shortcomings and are not prone to selfincrimination. Thus, in this article the assumption is proved that the adventurous person, although with a lower level than not adventurous persons are characterized by positive selfattitude, self-understanding, self-respect, autosympathy, arrogance.
\end{abstract}

Keywords: adventurism, tendency to adventurous behavior, self-treatment, property of personality, quantitative analysis, qualitative analysis.

Подано 10.02.2020

Рекомендовано до друку 24.02.2020 